\title{
Intelligent control algorithm for autonomous integrated power plants for Arctic regions
}

\author{
Yu. Sinyavsky ${ }^{1 *}$, E. Kirillova ${ }^{1}$ \\ ${ }^{1}$ Branch of the National Research University "MPEl" in Smolensk, Smolensk, Russia \\ *sinyavskiyyv@yandex.ru
}

\begin{abstract}
The article considers the information and technical aspects of an innovative autonomous integrated power plant management, including alternative energy sources and a diesel generator set, as well as controlled inverters that provide energy supply to consumers of various priority categories, which can be used in the Arctic regions of the Russian Federation. The main aspects of creating innovative systems are considered and it is determined that the creation of integrated energy systems requires a significant deepening of cooperation between national producers in order to ensure the scalability of integrated energy systems by ensuring the unity of information means of data exchange between individual modules and the control system. It is shown that a specific requirement for control systems of complex power plants is the requirement of high autonomy, including the ability to provide consumers with electricity under variable environmental conditions without direct intervention of operational personnel. The article substantiates the division of the information and algorithmic support of the control system of a complex power plant into two modules analytical and control. For the analytical module, an algorithm is proposed that ensures the development of control solutions in a complex energy system, ensuring the stability of energy supply to the most important consumers. At the same time, the algorithm provides an increase in the reliability of the energy storage device based on Li-lon batteries used in the system not only by eliminating excessive charge and deep discharge, but also by reducing the number of charge/discharge cycles. The solution of system autonomy problem is provided by a multivariate algorithm for predicting weather conditions using statistical data and methods for analyzing fuzzy time series. The intelligent control algorithm was implemented in $\mathrm{C}++$, the weather forecasting algorithms were implemented in Python using the ANFIS library.
\end{abstract}

Keywords: alternative energy, energy efficiency, control algorithms in the energy sector, fuzzy time series, forecasting

For citation: Sinyavsky Yu., Kirillova E. Intelligent control algorithm for autonomous integrated power plants for Arctic regions. Prikladnaya informatika=Journal of Applied Informatics, 2021, vol.16, no.4, pp.74-82. DOI: 10.37791/2687-0649-2021-16-4-74-82 


\title{
Интеллектуальный алгоритм управления автономными комплексными энергетическими установками арктического исполнения
}

\author{
Ю. В. Синявский ${ }^{1 *}$, Е. А. Кириллова ${ }^{1}$ \\ 1 Филиал ФГБОУ ВО «Национальный исследовательский университет "МЭИ"» \\ в г. Смоленске, Смоленск, Россия \\ *sinyavskiyyv@yandex.ru
}

\begin{abstract}
Аннотация. В статье рассмотрены информационно-технические аспекты управления инновационной автономной комплексной энергетической установкой, включающей в себя альтернативные источники энергии и дизель-генераторную установку, а также управляемые инверторы, обеспечивающие энергообеспечение потребителей различных категорий приоритета, которая может быть использована в арктических районах РФ. Рассмотрены основные аспекты создания инновационных систем и определено, что создание комплексных энергетических систем требует существенного углубления кооперации национальных производителей с целью обеспечения масштабируемости комплексных энергетических систем путем обеспечения единства информационных средств обмена данных между отдельными модулями и системой управления. Показано, что специфическим требованием к системам управления комплексными энергетическими установками является требование высокой автономности, в том числе способность обеспечивать потребителей электроэнергией при переменных условиях окружающей среды без непосредственного вмешательства оперативного персонала. Обосновано разбиение информационно-алгоритмического обеспечения системы управления комплексной энергетической установкой на два модуля - аналитический и управляющий. Для аналитического модуля предложен алгоритм, обеспечивающий выработку управляющих решений в комплексной энергетической системе, обеспечивающий стабильность обеспечения энергией наиболее важных потребителей. Одновременно алгоритм обеспечивает повышение надежности используемого в системе накопителя энергии на базе Lilon аккумуляторов не только на основе исключения избыточного заряда и глубокого разряда, но также путем сокращения количества циклов заряд/разряд. Решение задачи автономности системы обеспечивается многовариантным алгоритмом прогнозирования погодных условий с использованием статистических данных и методов анализа нечетких временных рядов.
\end{abstract}

Ключевые слова: альтернативная энергетика, энергоэффективность, алгоритмы управления в энергетике, нечеткие временные ряды, прогнозирование

Для цитирования: Синявский Ю. В., Кириллова Е. A. Intelligent control algorithm for autonomous integrated power plants for Arctic regions // Прикладная информатика. 2021. T. 16. № 4. C. 74-82. DOI: 10.37791/26870649-2021-16-4-74-82

\section{Introduction}

T he specifics of modern production and economic conditions determine the need for systematic, well-coordinated and interre- lated work of several individual economic entities for sustainable development in the strategic perspective. Technological progress, increased intensity and global competition significantly shorten the life cycles of products and services, 